\title{
The church's responsibility towards the social order: An Old Testament hermeneutic problem
}

\author{
A P B Breytenbach \\ Emeritus Professor: Department of Old Testament Studies \\ University of Pretoria
}

\begin{abstract}
There is a widespread conviction among conservative groups in the Afrikaans speaking mainline churches in South Africa that the church has a responsibility towards the structuring of society. This conviction is based on a reading of the Old Testament which can be traced back to Calvin. The article hypothesises that such a hermeneutic cannot be maintained in the aftermath of historicalcritical research in Biblical studies.
\end{abstract}

\section{INTRODUCTION}

There is a widely held conviction in the Nederduitsch Hervormde Kerk van Afrika (NH Church of Africa) ${ }^{1}$ that the church has a cultural task in the world (NHK 1995:316). If the articles and comments in the official publications of the other two churches in the Dutch reformed tradition (Dutch Reformed Church and Reformed Churches) in South Africa over the past three years are taken into account, it is clear that this conviction that the church has a cultural task is widely held among their members too. For the purpose of this article, I shall confine myself mainly to the $\mathrm{NH}$ Church of Africa and the tradition on which it is based.

There is no consensus among theologians about what precisely comprises culture. This obviously means that there are divergent views about the question of what the cultural task of the church is. In fact, there is a whole spectrum of standpoints on the matter. At the one end of the spectrum are those who think that the church should have a say in ordering every aspect of society. This means that the church should express its views on social, political, economical and other matters. This standpoint is usually supported by the conviction that God provided certain biblical principles according to which society should be ordered. A society ordered according to these

\footnotetext{
${ }^{1}$ This is one of the three traditional mainline churches among Afrikaans speaking people in South Africa.
} 
principles is a Christian society, and a government applying these principles could be typified as a Christian government. At the other end of the spectrum are those who think that the church is obliged solely to proclaim the gospel of salvation through Jesus Christ in and to the world. The church therefore has only the task of bearing witness and is not in the least concerned with the ordering of society. Where people believe this gospel, their lives and concomitantly their participation in society will obviously change. Between these two extreme stances there is naturally a whole range of possibilities, including that the church should concern itself only with the matters in which it has a direct interest, such as the upbringing and education of its children.

This article deals with the question of how the Old Testament functioned hermeneutically in establishing the conviction that the church does have a cultural task. Because of the divergent views on what should be understood by culture, and consequently also the difference in points of view on what exactly the cultural task of the church is, this article does not deal with a scientific definition of culture. After all, when the issue of whether or not the $\mathrm{NH}$ Church of Africa has a cultural task is debated in its ranks, a scientific definition of culture is not used either. The argument merely involves the question of whether or not the church should have a say in the way society is ordered through matters such as legislation on gambling, the observance of Sundays, abortion, the death penalty and other social issues (Steenkamp 1996:8).

The question of whether or not the church has a cultural task came strongly to the fore when the government changed in South Africa, and the three traditional mainline Afrikaner churches (those mentioned above) in particular lost control over society as a result. The debate often also concerns the maintenance of what can broadly be called Afrikaner culture. For example, the church is expected to take a stand on the position of the Afrikaans language in society (cf e g Die Hervormer 1991:4; 1994:1).

Therefore the issue essentially concerns the ordering of society as seen from the perspective of the group of people who regard themselves as the continuation of the traditional Afrikaner. The issue concerns a demand for the input of the institutional church in this ordering of society.

\section{THE USE OF THE OLD TESTAMENT IN ESTABLISHING THE CULTURAL TASK OF THE CHURCH}

\subsection{Calvin's hermeneutic points of departure}

It is common knowledge that the theological tradition of the NH Church of Africa relies strongly on Calvin's doctrine. It is also clear that theologians who 
believe that the church has a task concerning the ordering of society are closely allied to Calvin's beliefs and the Calvinist tradition (Pont 1986:73-75). In view of this, it is necessary to digress briefly to examine Calvin's hermeneutic stance toward the Old Testament.

\subsubsection{The Old Testament as the Word of God}

It is clear from Calvin's Institutes that he understood and treated the Old Testament as a timeless document with an unambiguous prescriptive message valid for all people in all times. Although there are differences, the Old and New Testaments are one Holy Scripture with essentially the same content and equal authority. This is clear from, inter alia, the following quotations:

FROM what has been said above, it must now be clear, that all whom, from the beginning of the world, God adopted as his peculiar people, were taken into covenant with him on the same conditions, and under the same bond of doctrine, as ourselves .... The covenant made with all the fathers is so far from differing from ours in reality and substance, that it is altogether one and the same: still the administration differs....What we propose to insist upon here may be reduced to three heads: - First, That temporal opulence and felicity was not the goal to which the Jews were invited to aspire, but that they were admitted to the hope of immorality, and that assurance of this adoption was given by immediate communications, by the Law and by the Prophets. Secondly, That the covenant by which they were reconciled to the Lord was founded on no merits of their own, but solely on the mercy of God, who called them; and, thirdly, That they both had and knew Christ the Mediator, by whom they were united to God, and made capable of receiving his promises.

(Calvin 1559, II:10, 1 \& 2)

In his discussion of the "distinction between the Old and the New

Testament." Calvin comes to the conclusion that the covenant "which God once ratified" was "eternal and unending" (Calvin 1559: II.11, 4).

These points of departure indicate that Calvin quotes the Old and New Testament on an equal footing in his arguments and dogma discussions.

\subsubsection{The Decalogue}

The Decalogue as a moral code has a special place in Calvin's treatment of the Old Testament. To Calvin the Decalogue is an all-encompassing code of conduct intended for all believers in all times. He states it as follows: 
The moral law, then, (to begin with it,) being contained under two heads, the one of which simply enjoins us to worship God with pure faith and piety, the other to embrace men with sincere affection, is the true and eternal rule of righteousness prescribed to the men of all nations and of all times, who would frame their life agreeably to the will of God.

(Calvin 1559, IV:20, 15)

However, the Decalogue is not intended solely for believers, but also offers the basic guidelines according to which society should be ordered.

Now, as it is evident that the law of God which we call moral, is nothing else than the testimony of natural law, and of that conscience which God has engraven on the minds of men, the whole of this equity of which we now speak is prescribed in it. Hence it alone ought to be the aim, the rule, and the end of all laws. Wherever laws are formed after this rule, directed to this aim, and restricted to this end, there is no reason why they should be disapproved by us, however much they may differ from the Jewish law, or from each other, ....

(Calvin 1559, IV:20, 16)

\subsection{The covenant in the Calvinistic tradition}

Calvin understood the relationship between God and all believers to be a covenant. This was the inevitable result of his hermeneutic point of departure that the covenant referred to in the Old Testament is essentially the same as the covenant established through Christ (see quotation above). The fact that there is only one covenant is particularly clear in Calvin's argument for infant baptism. He states that baptism and circumcision are essentially the same because the covenant's pledges are essentially the same for both (Calvin 1559: IV. 16, 2-5). In fact, it is one and the same covenant entered into with Jews and Christians. "For it is most evident that the covenant, which the Lord once made with Abraham, is not less applicable to Christians now than it was anciently to the Jewish people, and therefore, that word has no less reference to Christians than to Jews" (Calvin 1559, IV:20, 6).

Calvin's stance that the Old Testament is a timeless document with an unambiguous, prescriptive message for all people in all times leads him to interpret the covenant concluded between king and people in the Old Testament as a model for the relationship between the State and people in his own time too (Dreyer 1995:17-19). Following the example set by the good kings in the times of the Old Testament, every government should use the 
Decalogue as a basic rule (because it contains the true religion) to order society with a view to establishing "a public form of religion ... among Christians, and humanity among men" (Calvin 1559, IV:20, 3).

However, it was particularly the later followers of Calvin who further developed the theology of the covenant and so eventually provided a comprehensive foundation for the church's say in the ordering of society (see Pont 1986:32-38 for the historical development in the Netherlands in this regard). Concepts such as "theocracy" and "kingdom of God" became increasingly important in this theologising. Pont states the matter as follows:

The basis of this school of thought is that, in terms of baptism, all the people are part of or give shape to the covenant. In terms of this theocratic thinking, as stated in Art 36, [Belgic Confession] it is the duty of the authorities, as rulers by the grace of God, to maintain God's honour in public life so as to prevent the true service of God from being impeded by public godlessness. In this school of thought, the government should help to sanctify people's lives, because the Reformatory government should maintain in public life the two tables of the Law. This view regards the ideal of a holy national life, as found in Israel, as an example to be pursued. The Word orders the church and the State to co-operate and the State has a definite duty: so that everyone can honour and serve God (Belgic Confession, Art 36). The whole life and culture of the people should be Christianised so that the kingdom of God can be promoted in this manner ... This is the duty of the church, as baptised and covenanted people, namely to serve the State and the people with the Word of God so that the kingdom will gain stature among the people. This does not mean to say that the church includes the entire populace or that the populace determine the quality of the church, but that the church is the church of Jesus Christ in the national existence of that populace, so that through its existence and particularly through its preaching the commonwealth can be Christianised.The basis of this school of thought is that, in terms of baptism, all the people are part of or give shape to the covenant. In terms of this theocratic thinking, as stated in Art 36, [Belgic Confession] it is the duty of the authorities, as rulers by the grace of God, to maintain God's honour in public life so as to prevent the true service of God from being impeded by public godlessness. In this school of thought, the government should help to sanctify people's lives, because the Reformatory government should maintain in public life the two tables of the Law. This view regards the ideal of a holy national life, as found in Israel, as an example to be pursued. The Word orders the church and the State to co-operate and the State has a definite duty: so that everyone can honour and serve God (Belgic Confession, Art 36). The whole life and culture of the people should be Christianised so that the 
kingdom of God can be promoted in this manner ... This is the duty of the church, as baptised and covenanted people, namely to serve the State and the people with the Word of God so that the kingdom will gain stature among the people. This does not mean to say that the church includes the entire populace or that the populace determine the quality of the church, but that the church is the church of Jesus Christ in the national existence of that populace, so that through its existence and particularly through its preaching the commonwealth can be Christianised.

(Pont 1986:37f; my translation)

This theological point of view gained a foothold in the early history of the $\mathrm{NH}$ Church of Africa, particularly via the work of $\mathrm{W}$ á Brakel and those who are called the oude schrijvers (Pont 1986:53-60; 1991:786-789).

\subsection{Continuation in present times}

Calvin's hermeneutic points of view on the Old Testament and covenant and the later theologising on theocracy and the kingdom of God (as crystallised in the dogmatic reflection of a theologian such as á Brakel) apparently have followers even today in the ranks of theologians in the NH Church of Africa. This is clear from the following sympathetic assessment by Pont:

This, just like Retief's oath of office, lies fully within the vision of Calvinist theocracy in which people, church and government are an obvious and organic unit. This view cannot be called "Old Testamentary" without further ado, as if it had only limited validity. The Voortrekkers learnt from, inter alia, á Brakel that the Scriptures are a unit and that the Old Testament cannot be played off against the New Testament ...

It is probably due to the Voortrekkers' covenantal theology that they are quite consistently identified as "Old Testament believers". However, if it is taken into account that á Brakel describes the covenant of grace, of which Jesus Christ is the Mediator, as the covenant that was concluded immediately after the fall of man (Gen 3:15), and that all the other covenants only served to confirm the covenant of grace, it is understandable that the Old Testament should not be judged as having passed, but as being in principle at one with the New Testament.

In addition it is clear that to the Voortrekkers the description of people's life in the Old Testament was not a matter applicable only to Israel. From á Brakel and also the other oude schrijvers it is clear that the life of the people of Israel had a paradigmatic meaning, as this formed the basis for the substance that the Christian commonwealth should form. It is therefore perhaps also 
not so strange that the Voortrekkers sometimes referred to their leaders as "judges". In the pattern of Calvinist theocracy, the Voortrekkers structured the church in the world and structured the social pattern from the church and around the church so that the entire life of the people would be devoted to God's service and to God's honour. It is clear from the Old Testament that God himself demands that the entire life of the people - under the church and civil authority - should be to serve, praise and honour Him. The kingdom of God is not a matter that first comes to the fore in the New Testament, but it is the vocation and purpose of God's people, the covenanted people who have to live in the world as a holy people. It is therefore obvious that the Voortrekkers also and for that reason read the Old Testament so carefully, tried to emulate it and found parallels with the history of the people of old and their own existence. This did not make them "Old Testament believers" in the sense that they did not know Jesus Christ was the Mediator and Guarantor. In following á Brakel they read the Old Testament as an inseparable part of the Holy Scriptures, of which Jesus Christ was the centre. Perhaps Van Ruler's comment still holds true, namely that every theocracy cannot help but have an Old Testament character.

(Pont 1986:56-58; my translation)

In the current debate, the covenant is often used as the basis for the following arguments: God's covenant in the Old Testament demanded that society as a whole should be ordered in accordance with the will of God, as contained in the Decalogue and other commandments. The same applies in our own times, namely that God's covenant with people demands that society in all its parts should be ordered in accordance with the will of God.

\subsection{Summary}

The conviction among the members of the NH Church of Africa that the church has a task with regard to the ordering of society is a typical Calvinist legacy. This applies particularly to the point of view that the church has to bear witness to the government, or caution or encourage the government to organise society in such a manner that the Decalogue is the basic rule.

Matters that usually receive special attention include the rejection of religious equality (on the basis of the first commandment), the rejection of abortion (on the basis of the sixth commandment) and the maintenance or reintroduction of the death penalty (notwithstanding the sixth commandment!). As indicated, this point of view on the church's say in the ordering of society is very strongly founded on the Old Testament. This, in turn, is based on a specific understanding of the Old Testament. 


\section{EVALUATION AND CRITICISM}

\subsection{Calvin's position}

Calvin's use of the Old Testament reflects in all respects a contemporary understanding (De Greef 1984:253-263). It is typical of sixteenth and seventeenth century treatment of the Scriptures to

- use the Old Testament in a pre-critical manner by not taking its literary and historical context into account;

- interpret the Old Testament Christologically in a typological manner and to understand the Old Testament as the book of promises that were fulfilled in Christ;

- to do the exegesis of the Old Testament in such a manner that the results reflect sixteenth-century Reformed dogma;

- justify certain dogmatic theories by means of rational substantiation (Bosman et al. 1987:67).

This kind of treatment of the Scriptures was brought about by the polemics against the Pope as the official institution for interpreting ecclesiastical theory. The polemics found expression in, inter alia, slogans such as sola scriptura and scriptura sacra sui ipsius interpres. This particular kind of treatment of Scriptures was also due to the fact that the way in which New Testament and post-New Testament writers treated the Old Testament became the norm for their own treatment of the Old Testament. Although Luther, Calvin and their followers broke away from certain methods of Scriptural treatment, such as allegorical interpretation (cf Gl 4:21-31) and the fourfold sense of the Scriptures (John Cassian), they did not break with the basic premise in the New Testament, namely that, in addition to the ordinary meaning, the Old Testament also has a deeper meaning (sensus plenior), and that this deeper meaning is the real meaning (cf Eph 5:31 v).

Though it is understandable that, as a child of his times, Calvin read the Old Testament in a specific manner and was involved in a debate with different groups; and though it would not be fair to criticise Calvin and his contemporaries pedantically from a post-critical perspective (since they worked with Scripture from a pre-critical perspective), it nevertheless seems necessary to comment briefly on some aspects of Calvin's treatment of the Old Testament.

\subsubsection{The dogma of predestination as compelling hermeneutic principle} It is clear that Calvin was actually compelled, owing to his stance on predestination, to understand the Old Testament and in particular the 
covenant in the Old Testament as timeless and also essentially the same as that of the New Testament. When he, with reference to Augustine states "that all the saints mentioned in Scripture, from the beginning of the world, as having been specially selected by God, were equally with us partakers of the blessing of eternal salvation" (Calvin 1559, II:11, 10), he inevitably has to make the Old Testament say something else than what it usually states. He does this (as indicated) by working with a hidden meaning of the Old Testament. This covert meaning is brought home in a promise-fulfilment scheme, which he then "exploits" using interpretative methods such as quoting words out of context and by using typology (sensus literalis compositus).

\subsubsection{Rationalistic theologising}

Calvin also makes extensive use of rationalistic arguments which in a scholastic manner order the exegetic "result" in a final and "closed" dogmatic construct. For example, his standpoint that the patriarchs did not receive the land of Canaan as a promise, but that they received eternal life as a promise, is based on the argument that the difficult living conditions of Abraham, Isaac and Jacob and the fact that they did not possess the land of Canaan are proof that they expected eternal life! Calvin does this in connection with Hebrews 11:9. He states:

In declaring that he had spent his life in constant wretchedness, he denies that he had experienced the prosperity which had been promised him by the Lord. Jacob, therefore, either formed a malignant and ungrateful estimate of the Lord's favour, or he truly declared that he had lived miserable on earth. If so, it follows that his hope could not have been fixed on earthly objects .... If they were pilgrims and strangers in the land of Canaan, where is the promise of the Lord which appointed them heirs of it? It is clear, therefore, that the promise of possession which they had received looked farther. Hence, they did not acquire a footbreadth in the land of Canaan, except for sepulture; thus testifying that they hoped not to receive the benefit of the promise till after death.

(Calvin 1559, II:10; 12-13)

In exactly the same way, Calvin's rationalistic denigration of the sacrificial culture of the Old Testament is clearly aimed at strengthening the entire matter of sacrifices as shadows of the reality that would dawn in Christ (in other words, the promise-fulfilment scheme). For example, he states:

For what could be more vain or frivolous than for men to reconcile themselves to God, by offering him the foul odour produced by 
burning the fat of beasts? or to wipe away their own impurities by besprinkling themselves with water or blood? In short, the whole legal worship (if considered by itself apart from the types and shadows of corresponding truth) is a mere mockery.... But the type shows that God did not enjoin sacrifice, in order that he might occupy his worshippers with earthly exercises, but rather that he might raise their minds to something higher. This is clear even from his own nature. Being a spirit, he is delighted only with spiritual worship.

(Calvin 1559, II:7, 1; cf also II:11, 10)

It is this kind of theologising which seriously prejudices Calvin's otherwise masterly work to the critical reader, and leaves the overwhelming impression that Calvin's understanding of the Old Testament merely served to endorse the points of view he adopted in his own polemical situation. This also applies to his use of the Old Testament as the basis for ordering society.

\subsection{Pre-critical understanding of the Old Testament in the post-critical era?}

It is clear to me that theologians in the post-critical era can no longer maintain Calvin's hermeneutic points of departure, his manner of theologising and that of his followers. Reading the Old Testament as a timeless scripture with an unambiguous prescriptive message means that the questions and problems tabled during the past two centuries of dedicated study of the Old Testament are simply ignored. Development in the field of Old Testament studies in the past two centuries and the irrefutable results produced by research, make it unthinkable that the Old Testament could still be used with a "first naiveté" in a theological debate. Van Ruler for example comments on Luther's standpoint that Christ himself can be truly and historically found in the Old Testament, as follows: "As I see it, historico-critical work has now made this a complete impossibility" (Van Ruler 1971:73). This research was not only made possible by the Reformation (Van Ruler 1971:11), but was also done virtually without exception in authentic Reformation circles. As James Barr (1983:37) puts it:

... [I]t was the dynamics of Reformation theology that created the needs which biblical criticism was developed to answer. Take that great Protestant principle, the "plain sense of scripture", and add to it that other great guide to understanding, namely that one should "compare scripture with scripture": where do these lead but to what Wellhausen, among others, did? 
Understanding the relation between the Old and New Testaments as that of the fulfilment of promises, and therefore per se working with a "deeper meaning" of the Old Testament, means that the theologian is for example doomed to a selective reading of the Old Testament. Even worse, the Old Testament is in effect disempowered, because why would one read the Old Testament with the goal of discovering a hidden meaning in it, which is in any event written clearly, openly and frankly in the New Testament? The theologian who takes sensus plenior as point of departure when reading the Old Testament, is aligned, unwittingly and unintentionally, with Marcion.

Research in the field of Biblical Studies has also entailed another shift: the standard and criterion for assessing the validity of exegetic results are no longer ecclesiastical dogma as in Calvin's time, but in research itself (Barr 1983:108). This means that our prior understanding of the text (which is mainly ecclesiastically and dogmatically coloured) is no longer the benchmark for our understanding. Our prior understanding is critically questioned in the exegetic process, which in turn is a piece of research. This is sola scriptura in its pure form. Therefore it is unheard-of today to propose, as Calvin's followers did, the covenant (as they interpreted it themselves!) as a central concept in the Bible and then to interpret the Old Testament in terms of this concept.

\subsection{The "misunderstanding" of Reformation writings}

It is taken for granted in Reformatory circles that the Word of God comes to us in human words. This simply means that the historical context in which the books we call the Old and New Testaments were collected has to be taken fully into account in exegesis and in our systematising of the exegetic results.

This is conceded over a broad front. What is striking, though, is that many of the theologians who concede this, evade taking fully into account the historical situation of the documents of the Reformation. No account is taken of the fact that all the documents during the time of the Reformation were polemical. Moreover no account is taken of the fact that the Reformation, besides many other things, was also a democratisation process. The emphasis on the covenant between the populace and the State, the emphasis on the State's responsibility for an ordered society and the emphasis on the church's "say" in the State and community by means of the Ten Commandments, should be understood in the context of the polemics against the political power of the Roman Catholic Church and in the context of democratisation. If the Belgic Confession had not been a written defence in the special circumstances of the years from 1559 to 1561, there would probably never have been an Article 36 in this confession. The theology expressed in Article 36 is that of Calvin and the Reformation, but the theme of 
"civil authority" is a Fremdkörper in the Ecumenical Symbols and the rest of the three Reformed confessions of faith. While the contents of the abovementioned confessions and confession documents focus on man before God (his guilt, his redemption, his life in God's service - we could say man's salvation), Article 36 concerns a matter that has nothing to do with man's salvation, because the church has never ever had to depend on a worldly authority for its existence in the world. In fact, history shows that the true church invariably grew in times of State persecution. "Freiheit der Kirche ist nicht dort, wo sie Möglichkeiten hat, sondern allein dort, wo das Evangelium sich wirklich und in eigener Kraft Raum auf Erden schafft, auch und gerade wenn ihr keine solchen Möglichkeiten angeboten sind" (Bethge 1958:337). In view of this, the important place that Article 36 sometimes assumes in theological pondering over the existence of the church in a country should be seriously questioned. (Cf e g Pont 1986:60f where, in connection with the "theocratic thinking" stated in Article 36, the church is described as "the religious obverse side of the people residing in a country".)

\subsection{The Decalogue in Reformatory documents}

The special place that the Decalogue has in Reformatory documents should also be seen in context. The prominence Calvin gave to the Decalogue and which was also given substance in the Heidelberg Catechism can be traced back to the place Luther gave it in his catechetical teaching. Luther had to teach the basic content of the faith in a form people could memorise, especially children and the illiterate people in society. To this end, he selected the Ten Commandments, the Twelve Articles and the Lord's Prayer (Our Father). He also mentions in his preamble to the Großer Katechismus:

Das sind die nötigsten Stücke, die man zum ersten lernen muß, von Wort zu Wort verzahlen, und soll die Kinder dazu gewehnen, täglich, wenn sie des Morgens aufstehen, zu Tisch gehen und sich abends schlafen legen, daß sie es müssen aufsagen, und ihn nicht Essen noch zu trinken geben, sie hätten's denn gesagt. Desgleichen ist, auch ein iglicher Hausvater schuldig, mit dem Gesind, Knecht und Mägden zu halten, daß er sie nicht bei sich halte, wo sie es nicht können oder lernen wollen. Denn es ist mit nichte zu leiden, daß ein Mensch so rohe und wilde zei und solches nicht lerne, weil in diesen dreien Stücken kürzlich, gröblich und aufs einfältigste verfasset ist alles, was wir in der Schrift haben; denn die lieben Väter oder Apostel (wer sie gewesen sind) haben also in eine Summa gestellet, was der Christen Lehre, Leben, Weisheit und Kunst sei, wovon sie reden und handlen und womit sie ümbgehen. 
It is clear from this quotation that Luther regarded people's learning of inter alia the Ten Commandments as a rather civilising exercise (cf "ein Mensch so rohe und wilde"). Calvin took this aspect further and stated that the Ten Commandments were essential for an ordered society. Consequently the Ten Commandments became far more significant to Calvin and his followers than they were intended to be in the Old Testament. In Exodus and Deuteronomy the Ten Commandments are inseparably part of the covenant that God made with Israel (cf Ex 19:1-20:17; Dt 5:1-21). These are not laws, but rules of life by which the people who entered into a relationship with YHWH at Sinai could express their loyalty to $\mathrm{Him}$ (Dt 6:4-9). Therefore the real issue here is not the ordering of society, but the relationship which God in his mercy and ineffable love created with Israel (Dt 7:7-11). Voluntary compliance with the commandments is Israel's response to God's love, and such loyalty and gratitude in turn release a downpouring of love from God (Dt 7:12-15). The Ten Commandments are absolutely embedded in the relationship between God and Israel. The Ten Commandments do not have an independent existence outside such a relationship. That is why the stone tablets with the commandments were shattered into pieces when Israel broke its relationship with God (Ex 32:19).

It is therefore legitimate to perceive the Ten Commandments as a guideline for the gratitude of those whom God redeemed (Heidelberg Catechism, Lord's Day 34-44). But, as often occurs in Reformatory theology, it is a gross miscalculation to make the Ten Commandments into a law for ordering society, and equally as gross to propose that if the State forces the Ten Commandments on unbelievers they will live to God's honour.

\subsection{Theocracy and the kingdom of God}

The concepts "theocracy" and "kingdom of God" play, as indicated above, an important role in the theological circles that think the church has a task in ordering society. A theologian such as Van Ruler has for example constructed a whole theology around the concept of "theocracy" and the theologically and semantically related concepts of "kingdom of God" and "sanctification of the world" (cf e g Van Ruler 1945:153379; 1947a:4-141; 1947b:158-214; 1969:191-215). The Old Testament plays an immensely important role in this theology of theocracy (Stamm \& Vriezen 1956:399). Van Ruler (1971:29) states for example regarding Israel and the Old Testament: "They reflect what the living God has in view for man and the world: his kingdom, his image, the law, theocracy." For Van Ruler (1971:77) the kingdom of God is central to the Old Testament. In this dispensation it is essentially an earthly kingdom: "But the quintessence is to be found in politics in the broadest sense of the term: the state, social and economic life, culture - in a word, the sanctification of the 
earth" (Van Ruler 1971:91). According to Van Ruler, in this lies the value that the Old Testament has for the Christian church. The church learns in the Old Testament that what matters is not only the corpus Christi, but also the corpus Christianum.

The commentary by Vriezen on Van Ruler's standpoint that theocracy is the entscheidendes Offenbarungsfaktum in the Old Testament is still valid today (Stamm \& Vriezen 1956:399). He states inter alia: "Es ist nun die Frage, ob diese Theologie der Theokratie ... in dieser Form tatsächlich biblisch ist oder ob sie vielleicht doch von einem bestimmten systematisch-theologischen Geschichtswinkel aus bestimmte biblische Fakta in einer falschen Perspektive sieht und einseitig darstellt."

In addition to this, it can be stated that scholars of the Old Testament generally accept the theological diversity in the Old Testament today and that no eminent biblical scholar still maintains the stance that the Old Testament has a central theme which can be indicated by a term such as "kingdom" or even "covenant". The debate on the question of the Mitte of the Old Testament was settled more than three decades ago (cf Hasel 1972:77-103).

A theological debate on the question of whether or not the church has a cultural task was conducted in the Netherlands in the 1950s, inter alia pursuant to Van Ruler's point of view. It was chiefly a debate among systematic theologians. In the correspondence exchanged between Haitjema and Van Niftrik, Van Niftrik states "dat het Rijk, dat wij verwachten, niets anders is dan Jezus Christus, die wij verwachten" (Haitjema \& Van Niftrik 1956:19). Van Niftrik adds: "Theocratie? Ja! Maar dan verkondigingstheocratie. En niets meer! Ik meen op grond van de Schrift, dat wij niet meer mógen en kunnen zeggen" (Haitjema \& Van Niftrik 1956:22). Vriezen summarised the case for theocracy and the kingdom of God as follows:

Sie [die Kirche] hat die verborgene Theokratie zu glauben, auf das Reich Gottes zu hoffen und davon Zeugnis zu geben, ohne den Willen zu haben, Institutionen zu schaffen, die eine äuszere Christianisierung bringen würden. Jede solche Christianisierung hat die Gefahr der Repristinierung und würde zwangsmäszig wirken statt glaubensmäszig.

(Stamm \& Vriezen 1956:403v)

The point of view that the issue of faith is the kingdom of God, and accordingly also theocracy, does not mean that the church should (as the accusation is often made) in a monastic mental state withdraw from the world. On the contrary! Bonhoeffer states this as follows: 
[W]ir [kommen] mit unseren Utopien nicht über unser Sterben, nicht über unser Alleinsein, nicht über unseren Durst hinaus - sie gehören alle ganz zur verfluchten Erde. - Aber wir sollen nun auch gar nicht darüber hinaus kommen, sondern das Reich kommt zu uns in unser Sterben, in unser Alleinsein, in unseren Durst, es kommt dort, wo die Kirche in der Solidarität mit der Welt verharrt und allein von Gott das Reich erwartet.

"Dein Reich komme" - das betet nicht die fliehende fromme Seele des einzelnen, das betet nicht der Utopist und Schwärmer, der hartnäckige Weltverbesserer - das betet allein die Gemeinde Kinder der Erde, die sich nicht absondern, die keine besonderen Vorschläge zur Besserung der Welt anzubringen haben, die auch selbst nichts Besseres sind als die Welt, aber die nun in der Mitte, in der Tiefe, in der Altäglichkeit und Unterworfenheit der Welt gemeinsam ausharren, - weil sie nun eben einmal in diesem Dasein in wunderlicher Weise treu sind und unverwandt ihren Blick heften ... auf die Auferstehung Jesu Christi. Hier ist das Wunder schlechthin geschehen. Hier ist das Todesgesetz zerbrochen, hier kommt das Reich Gottes selbst auf Erden zu uns, in unsere Welt, ... Gottes Reich ist das Reich der Auferstehung auf Erden.

... Wir setzen Gott Grenzen, indem wir in erstohlener Demut sagen, Gott könne nicht zu uns kommen, ... Diese Demut ist nichts als der schlecht verhohlene Hochmut dessen, der selbst wissen will, was Gottes Reich ist, und der nun, in ebenso schlecht verhohlenem Eifer, selbst das Wunder tun will, selbst das Reich Gottes schaffen will, und der im Erstarken der Kirche, in der Verchristlichung von Kultur und Politik und Erziehung, in einem Neuwerden christlicher Sitte das Kommen des Reiches Gottes erblickt und damit nur wieder dem Fluch der Erde, in der das Reich Gottes als Schatz verborgen ist, verfällt.

(Bethge 1960:276f)

\subsection{The Old Testament as witness of a bygone order}

It is clear from the preceding that using the Old Testament as the foundation for the church's "cultural task" essentially concerns hermeneutic stances. The case of the hermeneutics of the Old Testament is so comprehensive that it cannot be fully discussed in an article of this scope. The following are just a few loose thoughts indicating the broad contours of my own understanding an understanding which to a large extent was wrested from the Hebrew text of the Old Testament.

The Old Testament speaks of an order which is irrevocably past. Part of this order that is finally past, is God's covenant with Israel, the stipulations of the covenant (laws), the Davidian monarchy and the cult in Jerusalem. This order with all its forms has ceased to exist because God took a new direction 
in Jesus Christ. He did this as sovereign Lord over his Word and as sovereign Lord over the world.

The shocking truth that God took a new direction in Christ is the root of the problem with the Old Testament that the church has faced through the centuries. That God is the absolute sovereign over his Word and the world is difficult to accept for those people who want to systematise everything God does and says, so that they can gain a measure of control over Him! Throughout all the centuries, people have tried to fit God into some scheme or other so that He could be dealt with more easily. Theologians "handle" God through metaphorical-theological constructs such as "covenant" of God, "kingdom" of God, "law" of God, "promises" of God, "will" of God, "honour" of God and many more. The purpose is invariably to make God subservient to their own theological and political convictions in their own particular circumstances, by means of their own metaphorical-theological construct. Theologians convert the embarrassment that the Old Testament witnesses a bygone order into an opportunity to make the Old Testament the source of authority for their own theological convictions.

The fact that the Old Testament deals with an order that has finally passed, that there is a radical break between the Old and New Testaments and that the Old Testament has been misunderstood and misused for many centuries, does not mean however that the Old Testament as the Word of God is of no use to the Christian church. God's sovereign decision in Christ does not make the Old Testament obsolete. The Old Testament is not in the first instance about a social order. God makes God self known to us in the Old Testament. The essence of this is that God enters into a relationship with people. In his relationship with people, God lets us know God's love, mercy, judgment, forgiveness, loyalty, omnipotence, and sovereignty. The Old Testament speaks in different ways about this real mercy and judgmental presence of God among people. God's relationship with people is expressed in terms of the covenant, the cult, the monarchy in Jerusalem, the order of wisdom, et cetera.

The religio-social circle in which witnessing of God's presence among people was given, to a large extent determined the "form of expression" of that presence. For example, the covenant comes strongly to the fore in the circles that were responsible for the so-called Deuteronomistic History. The cult is again largely the form of expression in the work of the Chronicler. Sometimes there was tension between these different social circles. Consequently, their witnessing of God's presence among people often reflected this tension. Genesis 2-11 betrays for example a prejudice against urban and political culture (Wittenberg 1995:439-457). In the Deuteronomistic History there is 
also a strong tendency (as in Hosea and other proto-Deuteronomic literature) to portray the kings and priests negatively and to make prophets (or rather prophetic words) the hope for the future (Breytenbach 1996:702-710). The Chronicler retells the monarchic history of the books of Samuel and Kings, obviously because the prejudice against the kings and cults did not find favour in a traditionalist circle where the priest-king of Jerusalem had for centuries been the symbol of God's presence among the people (cf Ps 110). Though prophets worked most of the miracles in the books of Samuel and Kings, and

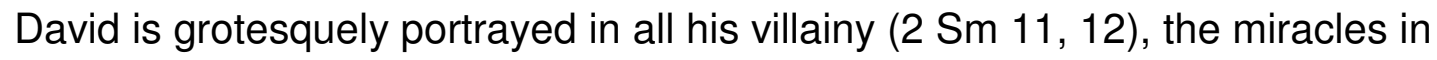
Chronicles take place at the temple and one reads nothing bad about David in these books.

This diversity in which God's all-too-human Word comes to us, ought to restrain us from positing a theological-metaphorical construct such as "the kingdom of God" or "the covenant" as fundamental truth; from interpreting the Old Testament in these terms; and, worst of all, from starting to institutionalise the matter by measuring the orthodoxy of other believers by this construct! Furthermore, the unique nature of the Old Testament as the all-too-human Word of God ought to restrain us from taking a section such as the Ten Commandments and making it the benchmark for human behaviour. Anyone could, for example, comply fully with the Ten Commandments without ever being compassionate to strangers (cf Lv 19:34). The ethical life of believers is in any case not determined by sets of rules. In accordance with the Old and the New Testaments, it is determined by what God did for humanity. The proclamation of the crucified and resurrected Christ in the New Testament is invariably the basis for the believers' ethical conduct (cf e $\mathrm{g} R \mathrm{Rm} 6: 1-14 ; 12: 1$ 21; Eph 2:1-22; 5:1-5; Col 3:1-4:1). In the Old Testament it is not the commandments as such, but God's liberation of the Israelites from Egypt that is the basis of Israel's devotion to $\mathrm{YHWH}$. The proclamation of God's great deeds to the community of faith determines how its members live (cf the paraenetical sections in Dt 4-11). To put it crudely: one cannot put a set of rules or principles (as some theologians understand the Ten Commandments) in one's pocket and then take them into the world and live a life of devotion to God. But one can, without knowing the Ten Commandments, go and live a life of devotion to God from the proclamation one hears every Sunday. The proclamation of the Word (of which the Ten Commandments are obviously part) determines the lives of believers in the world.

In our theologising, matters such as the kingdom of God (theocracy) and the covenant of God are the metaphors for attempting to express the inexpressible, namely that the omnipotent sovereign God communicated with us. Prerequisites for good theology are a sharply critical spirit about one's own attempts and a sincere humility before this God, who makes people witnesses 
of his love and who allows people to study that witnessing and to bear witness to it themselves.

\subsection{Two theological paradigms}

The nature of the topic being dealt with in this article compelled me to consult the work of systematic theologians over a wide front. The overriding impression this research left is that, behind the differences about whether or not the church has a cultural task, lie two profoundly opposing theological paradigms. A superficial reader would typify them as a difference between the Lutheran and Calvinist traditions and search for its roots in Luther's point of view on the duplex order, and Calvin's objection to this. But the matter is not quite so simple. For example, Luther did much stronger work on ordering communities in his "Bürgerpflicht" and in his "Pflicht als Theologe" than is generally accepted. As Kunst (1976:402) puts it:

Denn diese politische Verantwortung kommt nicht aus Zweckmä-
Bigkeitserwagungen oder aus dem Bewußtsein der Verpflichtung
für die Gemeinschaft, für Recht, Ordnung, soziale Gerechtigkeit
und was alles andere hier in Betracht kommt, sondern aus der
Bindung an das Wort Gottes, das an den ganzen Menschen und
alle Formen seiner Gemeinschaft gerichtet ist.

This does not differ much from Calvin's position. The differences about the church's cultural task should rather be sought on the one hand in a historically and confession-oriented theological paradigm and on the other, in a dialectically and critically oriented theological paradigm. In the theological tradition of the $\mathrm{NH}$ Church of Africa, the last-mentioned theological paradigm is a trajectory which can be traced from the ethicists in the Netherlands (Loader 1987:47-57) via the dialectical theology of Barth up to the present time, where its exponents are particularly at home among biblical scholars and some systematic theologians. The trajectory of the first-mentioned theological paradigm can be traced from Calvin via post-Reformation orthodoxy with influencing from Kuyper and in particular from Van Ruler up to the present time, where its exponents are particularly at home among church and dogma historians, and some systematic theologians.

Obviously, the differences between these two theological paradigms cannot be worked out here. This would require a study on its own. In such a study one would inter alia have to take carefully into account the influence that noting or rejecting the results of historical-critical research had and still have on the theological paradigms in ones own ecclesiastical tradition. Such a 
study would also for example have to take into account the following premise of Barth, the father of dialectical theology, and the effect it might have had.

Die sogenannte Kirchengeschichte antwortet auf keine selbständig zu stellende Frage hinsichtlich der christlichen Rede von Gott und ist darum nicht als selbständige theologische Disziplin aufzufassen. Sie ist die unentbehrliche Hilfswissenschaft der exegetischen, der dogmatischen und der praktischen Theologie.

(Barth, in Van Ruler 1947a:20)

\section{CONCLUSION}

It is my conviction that the church does not have a cultural task. Nor do the believers have a cultural task in the sense that this is a command from God. Someone can be a faithful child of God without ever taking an interest in education affairs or participating in an election, or whatever else. Such things are part of all people's Burgerpflicht which each performs or neglects in his or her own circumstances.

The church has carried out its task in the world if it has proclaimed the Word of God. This is not a matter to be treated lightly, as if proclaiming the Word is a powerless, unimportant event; proclaiming the Word is an interventionist matter. God rules the world through this proclamation! Being a witness of what God did and does in Jesus Christ is the way in which God used a perplexed group of people to establish the "kingdom for Israel" in all corners of the world (Ac 1:6-8). But then it should not be a word which convinces people of points of view (especially not theological points of view!) or organises them in some way or other. It must be the Word that places everyone, including the proclaimer, with his or her own life before God's love, his judgment and mercy. The church has done everything if it has proclaimed the Word, Jesus Christ, in this way.

The church has carried out its task to the world if it has entrusted the world to God. Rest, fear of God and honesty come to the world through united prayer to God - in the chaos comes room for the church to witness to the heathens about the one God and the one Mediator, the man Jesus Christ (1 Tm 2:1-8).

The church can intervene on behalf of its members with government or any other institution in the world, not because of political fervour or because the members have a certain political conviction, but on the basis of Christ's love for those in need, like Paul for Onesimus. This is uniquely the nature of the church of Jesus Christ, namely that it can plead far better than command (PhIm 1:8-19). 
Being a witness in the world, praying for the world and pleading to the world not only require self-criticism and deep humility before God, but also careful study of the Old and the New Testaments. In this difficult labour, God gives people a large apportionment of mercy. People discover that the God who became man in Jesus of Nazareth, is not a man when it comes to the guilt he has to assign to people and if it comes to love. One discovers this especially in the Old Testament (cf Hs 11).

\section{Works consulted}

Aalders, P F T 1973. Religie en politiek: De theokratische gedachte bij prof dr A A van Ruler, in Woord en werkelijkheid, 9-27.

Barr, J 1983. Holy Scripture: Canon, authority, criticism. Oxford: Clarendon.

Bethge, E (Hrsg) 1958. Dietrich Bonhoeffer: Ökumene; Briefe, Aufsätze, Dokumente, 1928 bis 1942. München: Kaiser.

Bethge, E 1960. Dietrich Bonhoeffer: Gesammelte Schriften, Dritter Band. München: Kaiser.

Bosman, H L (et al) 1987. Die Nederlandse Geloofsbelydenis: Ontstaan, skrifgebruik en gebruik. Pretoria: University of South Africa.

Breytenbach, A P B 1995. Nadenke oor die kerkbegrip: Enkele perspektiewe op grond van die Deuteronomistiese geskiedenis. HTS 51, 702-711.

Calvin, J 1559. Institutes of the Christian Religion, tr by $\mathrm{H}$ Beveridge, Edinburgh: Edinburgh Printing Company.

De Greef, W 1984. Calvijn en het Oude Testament. Groningen: Ton Bolland.

Die Bekenntnisschriften der Evangelisch-Lutherischen Kirche 1979. Gottingen: Vandenhoeck.

Die Hervormer 15 April 1991. Die Nederduitsch Hervormde Kerk en die onderwys, 4.

Die Hervormer 15 Augustus 1994. Verklaring oor moontlike aantasting van Afrikaans deur die uitsaaimedia, 1.

Dreyer, W A 1995. Kerk, volk en owerheid: 'n Hervormde perspektief. DD dissertation, University of Pretoria.

Haitjema, Th L \& Van Niftrik, G C 1956. Theokratie en eschatologie. Wageningen: Veenman.

Hasel, G F 1972. Old Testament theology: Basic issues in the current debate. Grand Rapids, MI: Eerdmans.

Kunst, H 1976. Evangelischer Glaube und politische Verantwortung: Martin Luther als politischer Berater seiner Landesherm und seine Teilname an den Fragen des öffentlichen Lebens. Stuttgart: Evangelisches Verlagswerk.

Loader, J A 1987. "Tertium datur" - oor die etiese waarheidsbegrip. HTS 43, 47-57.

Nederduitsch Hervormde Kerk van Afrika. Notule van die Algemene Kerkvergadering 1995. Archives of the Nederduitsch Hervormde Kerk, Pretoria.

Pont, A D 1986. Verbond en volkskerk. HTS 42, 28-76.

Pont, A D 1991. Die verhouding "kerk en volk" in die jare 1835-1900 in die Oorvaalse: 'n Terreinverkenning. HTS 47, 783-799.

Stamm, J J \& Vriezen, Th C 1956. "Die christliche Kirche und das Alte Testament": Zwei Stimmen zu A A van Ruler's gleichnamer Schrift. EvTh 16, 387-404. 
Steenkamp, J J (red) [1996]. 'n Eietydse getuienis op Hervormingsdag in die Nederduitsch Hervormde Kerk van Afrika 4 November 1995. s I.

Van Ruler, A A 1945. Religie en politiek. Nijkerk: Callenbach.

Van Ruler, A A 1947a. Het koninkrijk Gods en de geschiedenis. Nijkerk: Callenbach.

Van Ruler, A A 1947b. Droom en gestalte. Amsterdam: Holland.

Van Ruler, A A 1969. Theologisch werk, Deel I. Nijkerk: Callenbach

Van Ruler, A A 1971. The Christian church and the Old Testament, tr by G W Bromiley. Grand Rapids, MI: Eerdmans.

Wittenberg, G H 1995. Wisdom influences on Genesis 2-11: A contribution to the debate about the "Yahwistic" primeval history. OTE 8, 439-457.

Woord en werkelijkheid: Over de theokratie 1973. Nijkerk: Callenbach. 